\title{
Raising the Breast Health Awareness amongst Women in an Urban Slum Area in Alexandria, Egypt
}

\author{
Ibrahim F. Kharboush ${ }^{a, b}$ Hanaa M. Ismail ${ }^{a, b}$ Alaa A. Kandil ${ }^{a, c}$ Heba M. Mamdouh ${ }^{a, b}$ \\ Yasmine Y. Muhammad ${ }^{a, b}$ Omnia G. El Sharkawy ${ }^{a}$ Hassan N. Sallam $^{\mathrm{a}, \mathrm{d}}$ \\ ${ }^{a}$ Research Department, Alexandria Regional Center for Women's Health and Development (ARC),

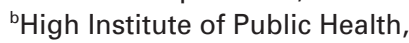 \\ 'Oncology Department, Faculty of Medicine, \\ ${ }^{\mathrm{d} D e p a r t m e n t}$ of Obstetrics and Gynecology, University of Alexandria, Egypt
}

\section{Keywords}

Breast cancer - Breast self-examination .

Breast awareness · Knowledge · Egypt

\section{Summary}

Background: Breast Cancer $(\mathrm{BC})$ is the most frequently occurring cancer among Egyptian women. This study aimed to determine the effectiveness of a health education program on raising the knowledge related to $B C$, its risk factors, and some related preventive practices among women living in an urban slum area in Alexandria. Patients and Methods: A pre-/post-test interventional study was conducted during 2009-2010 on a random sample of women aged $30-65$ years $(n=486)$ living in a slum area in Alexandria, Egypt. 20 health education sessions were carried out to educate the women on $B C$ risk factors and some preventive practices. Previously trained nurses educated the sampled women on breast self-examination (BSE). The women's knowledge and opinion about BC and their practice of BSE were evaluated before and 3 months after the intervention. Results: The findings indicated a significant increase in the mean knowledge score regarding $\mathrm{BC}$ and the mean opinion score regarding some $\mathrm{BC}$ risk factors. A significant increase in the practice of BSE was observed post intervention. Conclusion: This study confirms the effectiveness of intervention programs in improving the knowledge about BC risk factors and practice of BSE even in a group of women with a low literacy rate living in a slum area.

\author{
Schlüsselwörter \\ Brustkrebs · Brustselbstuntersuchung · \\ Brust-Bewusstsein · Wissen · Ägypten
}

\section{Zusammenfassung}

Hintergrund: Brustkrebs (BC) ist die am häufigsten auftretende Krebsart bei Frauen in Ägypten. Ziel dieser Studie war die Bestimmung der Wirksamkeit eines Gesundheitserziehungsprogramms zur Erhöhung der Kenntnisse im Zusammenhang mit BC, dessen Risikofaktoren und einigen BC-bezogenen präventiven Verhaltensweisen bei Frauen, die in einem städtischen Slum-Gebiet in Alexandria leben. Patienten und Methoden: Eine Prä-/post-Test-Interventionsstudie wurde während der Jahre 2009-2010 bei einer Stichprobe von 30- bis 65-jährigen Frauen ( $n=486)$, die in einem Armenviertel in Alexandria, Ägypten leben, durchgeführt. 20 Sitzungen zur Gesundheitserziehung wurden durchgeführt, um die Frauen über BC-Risikofaktoren und einige vorbeugende Verhaltensweisen aufzuklären. Zuvor ausgebildete Krankenschwestern trainierten die Frauen der Stichprobe in Brustselbstuntersuchung (BSE). Das Wissen und die Meinung der Frauen über BC sowie ihre Praxis der BSE wurden vor der Intervention und 3 Monate danach bewertet. Ergebnisse: Die Ergebnisse zeigen eine signifikante Zunahme in den Kenntnissen in Bezug auf BC und eine höhere Meinung in Bezug auf einige BC-Risikofaktoren. Nach der Intervention wurde eine deutliche Steigerung in der Praxis der BSE beobachtet. Schlussfolgerung: Diese Studie bestätigt die Wirksamkeit von Interventionsprogrammen zur Verbesserung der Kenntnisse über Risikofaktoren, BC und die Praxis der BSE auch in einer Gruppe von Frauen mit niedrigem Alphabetisierungsgrad, die in einer benachteiligten Gemeinde leben.

\section{KARGER \\ Fax +497614520714 \\ Information@Karger.de}

www.karger.com (c) 2011 S. Karger GmbH, Freiburg

$1661-3791 / 11 / 0065-0375 \$ 38.00 / 0$

Accessible online at:

www.karger.com/brc 


\section{Introduction}

Worldwide, breast cancer (BC) represents $10 \%$ of all cancers diagnosed annually and constituted $22 \%$ of all new cancers in women in 2000 , making it by far the most frequently occurring cancer in women. It will also become an important challenge to health services in developing countries in the coming decades [1].

The incidence, mortality, and survival rates for BC vary across the world's regions because of underlying differences in known risk factors, access to effective treatment, and the availability of organized screening programs [2]. Fatality rates tend to be higher in low-resource countries [1].

In Egypt, cancer registries reveal that $\mathrm{BC}$ is the most frequently occurring cancer among women, representing $18.9 \%$ of the total cancer cases ( $35.1 \%$ in women and $2.2 \%$ in men), with an age-adjusted rate of 49.6 per 100.000 persons [3]. BC among Egyptian patients has a younger age distribution, with the majority of cases occurring at 30-60 years of age. The median age at diagnosis is 49 years, 1 decade younger than the corresponding age in Europe and North America [4].

The etiology of BC is multi-factorial and cannot be directly linked to any single factor. The epidemiological literature supports a highly complex interplay between different exposures and host characteristics and between exogenous and endogenous hormones and an individual's genetic makeup [5]. A woman's age is the strongest risk factor for BC, and older women have a 10 times increased risk compared with younger women. Reproductive risk factors associated with the risk of $\mathrm{BC}$ include: menarche before the age of 11 years, menopause after the age of 54 years, and an age greater than 40 years at first full-term pregnancy [6]. The higher the number of fullterm pregnancies, the greater the protection. Women who breastfeed have a reduced risk compared with women who do not breastfeed [7]. Current knowledge suggests that oral contraceptive use is one of the weakest risk factors for $\mathrm{BC}$ [5].

Prevention or identification of $\mathrm{BC}$ at an early stage is of paramount importance in saving and improving the quality of life. Breast health awareness appears to be a pragmatic method for this. Creating breast health awareness appears to be an important prerequisite for early detection of $\mathrm{BC}$ in lowincome countries [8]. Although breast awareness has long been advocated as a health promotion intervention in many parts of the world, evidence suggests that women in general are still not breast aware.

Methods for early detection must be considered the best second choice for reducing the mortality, amongst which breast self-examination (BSE), clinical breast examination (CBE) by the treating physician, as well as ultrasound and mammography, are the secondary preventive methods used for screening in the early detection of BC [9]. According to the American Cancer Society (ACS), BSE is an option for women starting from the early 20's [10].
The combination of BSE and CBE seems to be an important available alternative in slum areas [11]. In areas where access to CBE and mammograms is difficult, BSE still detects $\mathrm{BC}$ early enough for treatment options.

$\mathrm{BC}$ is usually diagnosed at an advanced stage in Egypt, and studies revealed that population screening is rarely practiced in Egypt [9, 12-14]. Women living in slum areas suffer from the unavailability of services and poor health [15].

Given the importance of the BC problem in Egypt in terms of magnitude and severity, and that only few studies examined the awareness of BC among Egyptian women [16], this study was performed to evaluate the effect of a breast health awareness intervention program on the knowledge of a sample of women living in an urban slum area in Alexandria, Egypt.

\section{Patients and Methods}

\section{Study Population}

A random sample of 486 women living in the chosen area, in the age group of 30-65 years, was selected to participate in the study. Selected women who accepted to participate were invited to attend the intervention.

\section{Design and Sampling Technique}

A pre-test and post-test interventional study was conducted to evaluate the effects of BC and the BSE education program on a sample of women living in an urban slum area in Alexandria, Egypt. There is no accurate data about the population in these slums [17]. Based on the estimates available, a systematic random sampling of the houses (every 3rd house) in the area was used.

Before attending the health education sessions, women were interviewed to complete a pre-designed questionnaire. The questionnaire was designed after reviewing by 3 Egyptian experts $[18,19]$. The questionnaire was composed of 2 parts: The first part is used to investigate the socio-demographic data, some BC risk factors, and the family history among first- and second-degree relatives. The second part included questions about the knowledge of $\mathrm{BC}$ and the practice of BSE. The questionnaire was reused after 3 months from the end of the intervention (post-test).

\section{Intervention}

In a 2-day program, 5 affiliated nurses were trained by doctors on the correct time of the month to perform BSE, the steps of BSE, the proper patterns for palpating breast tissue, and the 3 early-detection guidelines as cited by the ACS [20].

The intervention was conducted in non-governmental organization (NGO) premises in the slum area. Over a period of 6 months, each week about 25 women were invited to attend the health education sessions. The sessions included interactive lectures and group discussions carried out by an oncologist, followed by training on BSE demonstrated by the trained nurses. The nurses used breast models to explain the BSE technique.

\section{Data Analysis}

Statistical analysis was performed using the SPSS program version 14. The knowledge score questions were measured by 0 and 1 categories, where 1 referred to the correct answer. A total knowledge score of 7 was calculated. The women's knowledge on BC risk factors was evaluated by calculating the proportion of women who recognized the correct answers 
on some $\mathrm{BC}$ risk factors before and after the intervention. In addition, the women were asked if they agreed or disagreed with some statements, to evaluate their opinion about some risk factors of $\mathrm{BC}$ and the preventive practices. The opinion score questions were measured on a $0-3$ scale, where 3 was the most satisfactory answer, giving a total score of 18 .

The McNemar test was used to compare the answers in the pre- and post-tests, while the paired t-test was used for comparison of the total scores. Logistic regression analysis was performed to detect the factors associated with performing BSE and the change in opinion scores after the intervention.

\section{Results}

The majority of the sampled women were currently married $(84.6 \%)$, with a mean age ( \pm standard deviation $(\mathrm{SD}))$ of 43.2 years $( \pm 9.01)$. About $3 / 4$ of the study participants were illiterate and $96.1 \%$ of them were housewives (table 1 ).

\section{Some Reproductive Characteristics and Influencing Factors of $B C$}

The age of menarche for $39.1 \%$ of the women was $<13$ years. The mean age of marriage $( \pm \mathrm{SD})$ of the ever-married participants was $19.3( \pm 3.9)$ years. Among the ever-married women, $97.5 \%$ had a history of at least 1 pregnancy, with $44.7 \%$ of them reporting to have 3 or 4 children (the mean number $( \pm \mathrm{SD})$ of children was $4.1( \pm 2.1)$ ).

About $90 \%$ of the sampled women reported that they breastfed all their children. The majority of the women reported on ever use of contraception (90.9\%), with hormonal contraception ever used by $38.1 \%$ of them. Only $8.6 \%$ of the women previously attended health education sessions. About $8.2 \%$ of the women had a family history of $\mathrm{BC}$, with a minor percentage reporting to have had any treatment of breast symptoms (table 2 ).

\section{BC Knowledge and Women's Opinion pre/post Intervention}

Prior to the intervention, only $18.3 \%$ of the study participants knew that all women are at risk of BC. The proportion of women who recognized a positive family history and menopause as risk factors of $\mathrm{BC}$ were $66 \%$ and $52 \%$, respectively. The total knowledge score of the participants $( \pm$ SD) was 2.77 ( \pm 1.2$)$. Post intervention, the mean total knowledge score increased significantly $(2.77 \pm 1.24$ pre intervention vs. $3.77 \pm 0.87$ post intervention; $p<0.001)$. Obesity and early menarche were not perceived as risk factors of $\mathrm{BC}$ by about $1 / 3$ of the sample, without significant changes between the pre and post data. Knowledge of the other risk factors showed significant changes between the pre- and post-test $(\mathrm{p}<0.05)$. The remaining risk factors were acknowledged by $>50 \%$ of the women in the post-test (table 3).

The opinion of the sampled women regarding some risk factors and preventive practices for $\mathrm{BC}$ showed a rather high mean $( \pm \mathrm{SD})$ total opinion score before the intervention (11.3 \pm 4.0 ), with significant improvement in their mean $( \pm$ SD)
Table 1. Socio-demographic characteristics of the sampled women

\begin{tabular}{lrc}
\hline Characteristic & Frequency & Percentage \\
\hline Marital status & 4 & \\
Unmarried & 411 & 0.8 \\
Married & 71 & 14.6 \\
Widow or divorced & & \\
Women's age, years & 83 & 17.1 \\
$<35$ & 189 & 38.9 \\
35-44 & 149 & 30.7 \\
$45-54$ & 65 & 13.4 \\
$\geq 55$ & & \\
Women's education & 363 & 74.7 \\
Illiterate or can just read and write & 50 & 10.3 \\
Primary and preparatory & 73 & 15.0 \\
Secondary education and higher & & \\
Women's occupation & 467 & 96.1 \\
Housewives & 14 & 2.9 \\
Workers & 5 & 1 \\
$\quad$ Employees/professionals & 486 & \\
Total & & \\
\hline
\end{tabular}

Table 2. Some risk factors for BC among the study sample

\begin{tabular}{|c|c|c|}
\hline Characteristics & $\begin{array}{l}\text { Frequency } \\
(\mathrm{n}=486)\end{array}$ & Percentage \\
\hline \multicolumn{3}{|l|}{ Family history of BC } \\
\hline Yes & 40 & 8.2 \\
\hline No & 446 & 91.8 \\
\hline \multicolumn{3}{|c|}{ Husbands' smoking status $(\mathrm{n}=416)^{\mathrm{a}}$} \\
\hline Yes & 198 & 47.6 \\
\hline No & 218 & 52.4 \\
\hline \multicolumn{3}{|c|}{ History of treatment for breast symptoms } \\
\hline Yes & 24 & 4.9 \\
\hline No & 462 & 95.1 \\
\hline \multicolumn{3}{|c|}{$\begin{array}{l}\text { History of treatment for gynecological } \\
\text { symptoms }\end{array}$} \\
\hline Yes & 255 & 52.5 \\
\hline No & 231 & 47.5 \\
\hline \multicolumn{3}{|c|}{ Ever use of contraception (470) } \\
\hline Yes & 428 & 90.9 \\
\hline $\mathrm{No}$ & 42 & 9.1 \\
\hline \multicolumn{3}{|c|}{ Number of children (470) } \\
\hline 1 or 2 & 97 & 23.2 \\
\hline 3 or 4 & 217 & 44.7 \\
\hline 5 or more children & 156 & 32.1 \\
\hline \multicolumn{3}{|c|}{ History of hormonal treatment } \\
\hline Yes & 28 & 5.8 \\
\hline No & 458 & 94.2 \\
\hline
\end{tabular}

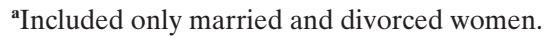

total opinion score post intervention $(12.9 \pm 2.8)$. Significant improvement in the mean opinion score was also noticed for the role of genetics, advancing age, effect of breastfeeding, effect of regular exercise, and practice of BSE (table 4).

Overall, significant improvement was shown in the percentage of women who knew how to perform BSE and in the percentage of women who ever practiced BSE after the intervention (table 5).

According to statistical regression analysis, a history of treatment of breast symptoms was associated with a higher knowledge score after the intervention. Furthermore, the women's total opinion score concerning risk factors was the only significantly associated factor with the practice of BSE during the last 6 months. 
Table 3. Mean knowledge scores regarding BC before and after the intervention

\begin{tabular}{|c|c|c|c|c|c|}
\hline \multirow[t]{2}{*}{ Risk factor } & \multicolumn{2}{|c|}{ Pre-test, correct responses } & \multicolumn{2}{|c|}{ Post-test, correct responses } & \multirow[t]{2}{*}{ p value* } \\
\hline & $\mathrm{n}$ & $\%$ & $\mathrm{n}$ & $\%$ & \\
\hline All women at risk of $\mathrm{BC}$ & 89 & 18.3 & 119 & 24.5 & 0.022 \\
\hline Women with family history of BC & 322 & 66.3 & 426 & 87.7 & $<0.001$ \\
\hline Women without children & 150 & 30.9 & 257 & 52.9 & $<0.001$ \\
\hline High age at first delivery & 208 & 42.8 & 261 & 53.7 & 0.002 \\
\hline Women post menopause & 253 & 52.1 & 285 & 58.6 & 0.031 \\
\hline Obese women & 181 & 37.2 & 166 & 34.2 & 0.337 \\
\hline Mean total knowledge score $^{\mathrm{a}}(\mathrm{SD})^{* *}$ & \multicolumn{2}{|c|}{$2.77(1.24)$} & \multicolumn{2}{|c|}{$3.77(0.87)$} & $<0.001$ \\
\hline
\end{tabular}

*McNemar test, p significant at $<0.05$.

***aired samples t-test, p significant at $<0.05$.

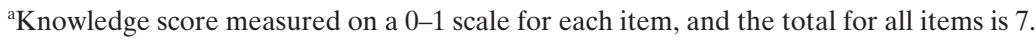

Table 4. Mean opinion scores regarding some risk factors and preventive practices of BC before and after the intervention

\begin{tabular}{|c|c|c|c|}
\hline Risk factor & Pre-test, mean (SD) & Post-test, mean (SD) & p value* \\
\hline $\begin{array}{l}\text { Genetic role } \\
\text { Age role }\end{array}$ & $\begin{array}{l}1.90(1.3) \\
1.04(0.9)\end{array}$ & $\begin{array}{l}2.37(1.1) \\
1.26(0.9)\end{array}$ & $\begin{array}{l}<0.001 \\
<0.001\end{array}$ \\
\hline $\begin{array}{l}\text { Role of psychological factors } \\
\text { Effect of breastfeeding } \\
\text { Effect of regular exercise } \\
\text { Regular BSE } \\
\text { Mean total opinion score }{ }^{\text {a }}(\mathrm{SD}) * *\end{array}$ & $\begin{array}{r}1.93(1.2) \\
2.32(1.1) \\
1.96(1.2) \\
2.20(1.2) \\
11.30(4.0)\end{array}$ & $\begin{array}{r}1.83(1.1) \\
2.44(0.8) \\
2.38(0.9) \\
2.55(0.9) \\
12.90(2.8)\end{array}$ & $\begin{aligned} & 0.192 \\
& 0.043 \\
< & 0.001 \\
< & 0.001 \\
< & 0.001\end{aligned}$ \\
\hline
\end{tabular}

*McNemar test, p significant at $<0.05$.

**Paired samples t-test, $\mathrm{p}$ significant at $<0.05$.

${ }^{\mathrm{a}}$ Opinion score measured on a $0-3$ scale for each item, and the total for all items is 18 .

Table 5. Practice of BSE before and after the intervention

\begin{tabular}{|c|c|c|c|c|c|}
\hline \multirow[t]{2}{*}{ Variable } & \multicolumn{2}{|c|}{ Pre-test } & \multicolumn{2}{|c|}{ Post-test } & \multirow[t]{2}{*}{$\mathrm{p}$ value } \\
\hline & $\mathrm{n}$ & $\%$ & $\mathrm{n}$ & $\%$ & \\
\hline \multicolumn{6}{|l|}{ Know how to do BSE } \\
\hline Yes & 64 & 13.2 & 485 & 99.8 & $<0.001$ \\
\hline No & 422 & 86.8 & 1 & 0.2 & \\
\hline \multicolumn{6}{|c|}{ Last time for practicing BSE } \\
\hline 1 month & 9 & 1.9 & 34 & 7.0 & $<0.001$ \\
\hline 6 months & 17 & 3.5 & 353 & 72.6 & \\
\hline Never had & 430 & 88.4 & 2 & 0.4 & \\
\hline Total & 486 & 100.0 & 486 & 100.0 & \\
\hline
\end{tabular}

\section{Discussion}

The present study revealed that, in spite of the low education level ( $75 \%$ women were illiterate or could just read and write) and low information about BC and BSE, the intervention dramatically changed the participants' knowledge on risk factors and BSE. A significant improvement was observed in the women's knowledge score regarding risk factors.

The present findings illustrate the unsatisfactory basic knowledge of the sampled women on $\mathrm{BC}$ risk factors prior to the intervention. This may be due to the shortage of BC-related health education programs in primary health care facilities and in the media [21]. Women's limited knowledge on BC has been identified elsewhere in developed and developing countries [22].
Similar to the present findings, many studies from both developing and developed countries illustrated the effectiveness of intervention programs in increasing the knowledge on $\mathrm{BC}$, its risk factors and the awareness for BC screening [23, 24]. The pre-intervention mean opinion score of some protective factors like breastfeeding was relatively high, reflecting cultural and religious factors encouraging breastfeeding [25].

The participants showed poor understanding of some BC risk factors, specifically obesity and early menarche. This may be explained by the local culture where obesity and early menarche are seen as signs of fecundity and good health.

Although the effectiveness of BSE remains controversial [26], it holds some promise of early detection of BC, especially in areas where secondary intervention facilities are scarce [27]. 
In conclusion, the results of this study confirm that an intervention program on $\mathrm{BC}$ improves the knowledge scores of the risk factors and BSE practice even in a group of women with low literacy rate living in slums.

\section{Disclosure Statement}

The authors report no conflicts of interests.

\section{References}

1 EMRO Technical Publications Series; in Khatib O, Modjtabai A (eds): 30WHO: Guidelines for the early detection and screening of breast cancer. Cairo, World Health Organization Regional Office for the Eastern Mediterranean, 2006.

$\checkmark 2$ Althuis MD, Dozier JM. Anderson WF, Devesa SS, Brinton LA: Global trends in breast cancer incidence and mortality 1973-1997. Int J Epidemiol 2005;34:405-412.

3 Ibrahim AS, Hussein H, Ismail K, Hablas A, Bar IA: Cancer profile in Gharbiah - Egypt. Methodology and Results 1999. Tanta, Middle East Cancer Consortium, 2002.

4 Elattar I, Ali-Eldin N, Moneer M, Elbasmy A: Cancer registry. Cairo, National Cancer Institute of Egypt, 2002-2003.

$>5$ Kahlenborn C, Modugno F, Severs WB: Oral contraceptives and breast cancer. Mayo Clin Proc 2008;83:849-850; author reply 850-841.

6 Rosner B, Colditz GA, Willett WC: Reproductive risk factors in a prospective study of breast cancer: The nurses' health study. Am J Epidemiol 1994:139:819-835.

7 Collaborative Group on Hormonal Factors in Breast Cancer: Breast cancer and breastfeeding: Collaborative reanalysis of individual data from 47 epidemiological studies in 30 countries, including 50302 women with breast cancer and 96973 women without the disease. Lancet 2002;360:187195.

8 Rao R, Nair S, Nair N, Kamath V: Acceptability and effectiveness of a breast health awareness programme for rural women in India. Indian J Med Sci 2005;59:396-403.
9 Omar S, Khaled H, Gaafar R, Zekry AR, Eissa S, El-Khatib O: Breast cancer in Egypt: A review of disease presentation and detection strategies. East Mediterr Health J 2003;9:448-463.

10 Lee E: Breast self-examination performance among Korean nurses. J Nurses Staff Dev 2003; 19:81-87.

11 Miller AB: Practical applications for clinical breast examination (CBE) and breast self-examination (BSE) in screening and early detection of breast cancer. Breast Care 2008:17;20-23.

12 Abdel-Fattah M, Lotfy N, Bassili A, Anwar M, Mari E, Bedwani R, Tognoni G: Current treatment modalities of breast-cancer patients in Alexandria, Egypt. Breast 2001;10:523-529.

$\checkmark 13$ El Saghir N, Khalil M, Eid T, El Kinge A, Charafeddine M, Geara F, Seoud M, Shamseddine A: Trends in epidemiology and management of breast cancer in developing Arab countries: A literature and registry analysis. Int J Surg 2007;5:225-233.

14 Elzawawy AM, Elbahaie AM, Dawood SM, Elbahaie HM, Badran A: Delay in seeking medical advice and late presentation of female breast cancer patients in most of the world. Could we make changes? The experience of 23 years in Port Said, Egypt. Breast Care 2008;3:37-41.

15 Kharboush IF, Youssef AA, Makhlouf MM, Zaghloul AA, El-Hamid AA, El Masry AG: Women health in poor urban settings in Alexandria. J Egypt Public Health Assoc 2005;80:321-348.

16 Abdel-Fattah M, Zaki A, Bassili A, El-Shazly M, Tognoni G: Breast self-examination practice and its impact on breast cancer diagnosis in Alexandria, Egypt. East Mediterr Health J 2000;6:34-40.
17 Nawar L, El Kotkat H, El Helw N, Abu Elazm H, Abd Elfatah N: Informal settlement in governorates of Arab Republic of Egypt - analytical study. Cairo, The Egyptian Cabinet, Information and Decision Support Center, 2008.

18 Nour SA, Ragheb MS: Factors associated with breast self examination among cancer patients in Alexandria. Bull High Inst Publ Health 1988;18:677-694.

19 Zaky El-Deen M, Mitwally HH, Salem YM, Shukri R: Health beliefs of senior nursing students regarding breast cancer and breast self examination. Bull High Inst Publ Health 1991;21:285-292.

20 American Cancer Society: Cancer Facts and Figures 2005. www.cancer.org.

21 Milaat WA: Knowledge of secondary-school female students on breast cancer and breast selfexamination in Jeddah, Saudi Arabia. East Mediterr Health J 2000;6:338-344.

22 Dandash K, Al-Mohaimeed A: Knowledge, attitudes, and practices surrounding breast cancer and screening in female teachers of Buraidah, Saudi Arabia. Int J Health Sci 2007;1:75-85.

23 Devi R, Singh MM, Kumar R, Walia I: An effective manual on breast self-examination. World Health Forum 1998;19:388-389.

$24 \mathrm{Lu}$ ZJ: Effectiveness of breast self-examination nursing interventions for Taiwanese community target groups. J Adv Nurs 2001;34:163-170.

25 Shaikh U, Ahmed O: Islam and infant feeding. Breastfeed Med 2006;1:164-167.

26 Larkin M: Breast self examination does more harm than good, says task force. Lancet 2001;357:2109.

27 Hill D, White V, Jolley D, Mapperson K: Self examination of the breast: Is it beneficial? Meta-analysis of studies investigating breast self examination and extent of disease in patients with breast cancer. BMJ 1988;297:271-275. 